\title{
Revising workers participation in regional innovation systems: a study of workplace innovation programmes in the Basque Country.
}

\section{Egoitz Pomares}

\begin{abstract}
The article analyses two workplace innovation programmes from the perspective of regional innovation systems and the design of public policies. In this sense, the programmes are described as political tools that are part of the Science, Innovation and Technology Plan 2020 of the Basque Autonomous Community. The regional perspective and the participation of workers are key matters that acquire relevance within the framework of European smart specialisation policies, as well as for regional development and cohesion.
\end{abstract}

Keywords: Workplace innovation, programmes, regional innovation system, innovation policy 


\section{Introduction}

Regions are considered to be decisive for economic growth and social cohesion in the EU. Regional ecosystems are strategic spheres of production capacity and the creation of quality employment. Since the early 1990s, the popularity of the concept of regional innovation (Asheim \& Gertler 2005) leads us to consider the region as an adequate scale for the support of innovation-based learning economies Doloreux \& Parto 2005). Since 2014 the Smart Specialisation Strategies, in particular those that focus on SMEs, are the central core of the EU's regional policy (European Commission, 2012).

Workplace Innovation is a concept with a track record in European politics (Pot et al. 2016). Directly related to the participation of workers due to its origins in sociotechnical systems (STS), the term has been reflected in public policies in the form of tools or programmes that date back to the 1960s.

Today, the participation of workers and promotion by means of programmes have acquired certain relevance in the search for solutions for the simultaneous improvement of productivity and the quality of jobs. Aspects that are directly related to the regional sphere. Given the importance of innovation and micro-factors, regions have become essential spaces for building competitive advantages and, therefore, for the development of territorial strategies (Navarro 2015).

The Basque Country is a good case, due to its high level of political autonomy (Cooke \& Morgan 1998), its innovation system (Cooke et al. 2000) and the positive external assessments (OECD 2011; Morgan 2013). As a result, the article presents two programmes to foster the participation of workers in the Basque Country. The article is organised as follows; the first section defines the theoretical framework based on the regional innovation systems and policies. The second section contains different perspectives on the participation of workers in innovation policies. The third section revises the instruments for the design of these types of policies. The fourth section describes the Basque Country's innovation system and the two Participation Programmes. The article concludes with a discussion section, and conclusions and considerations about the orientation and design of these policies within the regional context.

\section{Innovation within the regional context.}

The theory of Systems of Innovation (SI) (Freeman 1987; Lundvall 1992) has had a huge influence on the design of policies (OECD 2005, 2011). Based on this theory, innovation is a non-linear interactive process, in which stakeholders interact with a variety of other organisations and institutions. This process is characterised by reciprocity and feedback mechanisms that determine the success of the innovation. Within this theoretical framework regions are considered as important bases of political, economic and social coordination (Lundvall \& Borrás 1997: 39), a matter that has acquired relevance in the theoretical, empirical and political field (Asheim et al. 2011).

An approach based on a regional innovation system (RIS) is a strategic instrument for the analysis and implementation of regional innovation policies (Asheim 2007) to the extent that it responds to specific features, challenges and needs in each region (Tödtling \& Trippl 2005; Tödtling et al. 2013; Asheim et al. 2013). The RIS has been conceptualised in a limited sense and in a broad sense (Lundvall 1992; Asheim \& Gertler 2005). The limited definition mainly includes the R\&D functions of universities and research institutes in a top-down model of scientific and technological policies, while the broad definition includes the entire range of organisations of the region's learning and innovation system (Asheim \& Gertler 2005).

Similarly, innovation policies can also be classified in a strict or broad sense (see Edquist 1997, 2001; Edquist et al. 2009; Schienstock \& Hämäläinen 2001). Traditionally, the goal of the innovation policy has been the development and dissemination of technology, mainly through the production of new products or processes (Lundvall 1992). While according to the strict vision, the policy must have a 
fundamentally technological component and is determined from the top down, in a broad innovation policy the process is observed by the interaction that arises from the collaboration between different stakeholders as it adds a variety of sources of knowledge and interactions in organisational processes (Edquist et al. 2009). This means acquiring a conception that transcends R\&D policies and technological innovation towards aspects such as organisational learning and innovation (Cooke et al. 2000, Asheim et al. 2003; Lundvall 2004). In other words, an innovation policy with such a broad foundation concurs with the perspective of the innovation system that defines it as an interactive learning system focused on the creation of, among others, social innovations ${ }^{1}$ (Lorenz \& Lundvall 2006).

The two conceptions of the policy are related to the different forms of innovation (Jensen et al. 2007). The forms of innovation show the differences of the learning and innovation processes in that they indicate the main ways in which companies organise and produce innovations and learning. While the STI (science, technology \& innovation) form of innovation is of a restrictive nature (offer) and is based on a strategy marked by a scientific drive with a clear technological vocation, the DUI (doing, using, interacting) form is market-oriented (demand) and focuses on the development of organisational skills and innovations (Jensen et al. 2007). This is why the limited version of the RIS concurs with the STI innovation form, while the broader definition is associated with the DUI form (Lundvall 2008). However, studies point out the fact that the companies which combine the DUI and STI innovation forms are generally more innovative than companies that focus on just one of the forms (Jensen et al. 2007: 685).

Within this framework, the government is considered to be a core stakeholder (e.g. Borrás \& Edquist 2013; Woolthuis et al. 2005). Traditionally, government action has been aimed at solving the market's deficiencies, limiting the action and intervention of public policies for the creation of incentives in R\&D (e.g. see Kline \& Rosenberg 2010; Metcalfe \& Hughes 1993). The (neoclassical) approach downplays the importance of the specific institutional framework in which the innovation is carried out. Starting with the interactions between stakeholders and institutions, the theory of SI has identified others as a starting point in the design of regional innovation policies (Tödtling \& Trippl 2005).

According to certain studies (Edquist 2001; Borrás et al. 2009; Chaminade \& Edquist 2006) innovation policies must be designed to respond to specific problems, which correspond to the deficiencies of the innovation system. These problems have been classified into two types; as errors in the interaction of the system's components or as errors derived from the operation of the system (Woolthuis et al. 2005; Chaminade \& Edquist 2006). In this article we will focus on matters related to the former.

The approach of the broad innovation policy (see Edquist et al. 2009) involves, in addition to the technological focus, the inclusion of other innovations. In line with these arguments Piirainen \& Koski (2003; 2004: 320-322) identify three approaches in innovation policies; the traditional approach, the reduced systemic approach and the broad systemic approach. Based on this classification, differences in five aspects of the innovation policies are established. These aspects include features that range from the policy's objectives, the national/regional competitive base, the innovations pursued or desired, the justification for the public intervention and the activities associated with the innovation. This approach can be summarised as follows:

- The objective of the traditional innovation policy is to generate economic growth via the promotion of technological advances and support for linear scientific policies.

\footnotetext{
1 Social innovations have been conceptualised in the literature as "organisational innovation" (Hage 1999; Lam 2004), "workplace innovation" (Totterdill 2010; Pot 2011), and "social innovation at the workplace" Eeckelaert et al. 2012). A broader study on the concept can be found in Workplace innovation: Theory, research and practice (Oeij et al. 2017)
} 
- The objective of the narrow systemic innovation policy includes aspects related to the dissemination of technology, considering innovation due to its interactive nature.

- The broad systemic innovation policy bases the justification of the intervention on the weaknesses and deficiencies of the system, meaning that its objective is to promote aspects such as innovation, growth, cohesion and social well-being.

Similarly, it has been argued that (technological and industrial) policies should be designed broadly to take into account the social context, as the learning process is conceptualised as "an interactive and socially integrated process" (Lundvall 1999: 20).

The change from a narrow innovation policy to a broader one is a change in many aspects. The examples of how to integrate the users in the innovation processes by means of innovation policies are therefore scarce. Some of them can be found in public programmes and policies oriented towards the promotion of participation; in particular models characterised as divergent from traditional designs (Arnkil 2004; Arnkil et al. 2010), such as the case of Finland, where the government's role in the development of the workplace and in the innovation policy has been stronger than in other European countries (Alasoini 2016: 69).

\section{Participation in the context of innovation policies.}

In a scenario dominated by robotisation, automation and digitalisation, innovation policies in a broad sense must, in addition, facilitate the adaptation of workers by generating a collective learning process in an inclusive and participatory manner. This would be based on an interactive or recursive innovation model, including a relatively large number of workplaces, $R \& D$ units and other stakeholders in a permanent interaction with a long-term view (Alasoini 2006).

In general terms, the participation of workers has been conceptualised from two perspectives. The first refers to an integrating vision, the main argument for which is found in the effects of participation on efficiency. This approach is understood as a tool, a style and management technique used to persuade workers who participate in the achievement of the company's objectives and goals. The second corresponds to a critical paradigm of the Taylorist organisation of work, and seeks a balanced decision-making power between work and capital (industrial democracy) (Lahera 2004).

The participation of workers mainly comes in two forms; direct participation and indirect participation (carried out by means of representatives). The combination of both forms of participation has been conceptualised as the employee voice (Boxall \& Purcell 2011).

Despite the importance of the traditional forms of representative and direct participation, the participation of workers in processes and in decision-making that is strategic for the organisation is decisive, in particular within the context of rapid technological change, as a method to create novel solutions (Alasoini 2012: 262). Aside from the differences between one form and the other, the term participation is understood here in a broad sense; in other words, as the different institutions and organisations, forms, levels and mechanisms by which employees directly and/or through representatives can influence matters related to the organisation of work and which have an impact on the operation and decision-making of a company.

Pot (2011) defines this type of participation as "new and combined interventions in the fields of work organisation, human resource management and supportive technologies". In this sense, there is a large amount of academic literature that classifies the new forms of workplaces identified as "innovative, high-performance, new, or flexible" (Bauer 2004). Despite the differences in the terms, the transformation from a hierarchical type of organisational culture to more flexible structures and horizontal relationships of power are at the core of the concept of workplace innovation. However, Alasoini stresses that "the concept is not limited to the adoption of a ready-made set of 'high- 
performance' work practices, but refers to collaboratively constructed changes in a company's organisational and management practices that lead to simultaneous improvements in productivity (e.g. work productivity, product quality, process flow) and quality of working life (e.g. opportunities for development and the influence of employees on the work, employee well-being) and that also supports other types of innovation" (Alasoini 2011: 25).

Alasoini argues that in the industrial relations-based policy and in the science and technology-oriented innovation policy, the participation of workers has been approached as a method for the adoption of new solutions developed jointly by the management and external experts (Alasoini 2011). The broad participation of employees in innovation activities within companies must be backed by management processes and practices that are based on management principles different to those used in the Taylorist work organisation model (Alasoni 2012; Cressey et al. 2013). The author argues that limiting participation to the adoption of specific management and organisation practices can be considered as corrective measures for problems derived from technological change, production and organisation models (Alasoini 2004, 2005; Alasoini et al. 2005).

Table 1: different policy rationales on participation

\begin{tabular}{|c|c|c|c|}
\hline & $\begin{array}{l}\text { Industrial relations- } \\
\text { based workplace } \\
\text { development policy }\end{array}$ & $\begin{array}{l}\text { Science and technology- } \\
\text { oriented innovation policy }\end{array}$ & $\begin{array}{l}\text { Broad-based innovation } \\
\text { policy }\end{array}$ \\
\hline $\begin{array}{l}\text { Forms of } \\
\text { participation }\end{array}$ & $\begin{array}{l}\text { Direct and representative } \\
\text { participation }\end{array}$ & $\begin{array}{l}\text { Direct and representative } \\
\text { participation }\end{array}$ & Workplace Innovation \\
\hline $\begin{array}{l}\text { Typical objects } \\
\text { of participation }\end{array}$ & $\begin{array}{l}\text { Work tasks, work } \\
\text { organisation and working } \\
\text { conditions }\end{array}$ & $\begin{array}{l}\text { New products and } \\
\text { processes }\end{array}$ & $\begin{array}{l}\text { New products, services, } \\
\text { processes, business models, } \\
\text { work organisation, etc. }\end{array}$ \\
\hline $\begin{array}{l}\text { Rationale of } \\
\text { participation }\end{array}$ & $\begin{array}{l}\text { Employees have the right } \\
\text { to participate through } \\
\text { delegation, consultation, } \\
\text { hearing or having access to } \\
\text { relevant information. } \\
\text { Collaboration between } \\
\text { management and } \\
\text { employees improves the } \\
\text { quality and novelty value } \\
\text { of new solutions. }\end{array}$ & $\begin{array}{l}\text { Participation helps } \\
\text { overcome employee } \\
\text { resistance to the adoption } \\
\text { of new solutions. } \\
\text { Adapt solutions, developed } \\
\text { jointly by management and } \\
\text { experts, to better suit local } \\
\text { conditions by giving } \\
\text { employees an opportunity } \\
\text { to implement small } \\
\text { adjustments. }\end{array}$ & $\begin{array}{l}\text { Participation is a key } \\
\text { success factor in complex } \\
\text { environments where } \\
\text { networking, fast renewal } \\
\text { and innovation are central } \\
\text { competitive factors. } \\
\text { Generates collective } \\
\text { learning and reinforces a } \\
\text { sense of inclusiveness } \\
\text { among employees in } \\
\text { connection with rapid } \\
\text { changes. }\end{array}$ \\
\hline
\end{tabular}

Source: Alasoini 2013.

Alternatively to this perspective, the participation of workers from the viewpoint of a broad policy surpasses the traditional vision of industrial relations and the activity of technology-oriented innovation, incorporating workers as key factors of the competitiveness of organisations and including workers in innovation activities as a factor that supports the quality of work, respectively (Alasoini 
2012: 256). From this approach Alasoini (2016: 99) argues that the strategies of the programmes must include 1) elements that help to improve productivity and QWL simultaneously at a micro (e.g. local and regional organisations) and macro levels (e.g. the regional level), and, 2) elements that facilitate the construction of bridges between the micro and macro levels.

From the perspective of regional development, Totterdill (1999: 28) argues that a workplace innovation-based competitiveness model involves an alternative approach with respect to participation and the organisation of work. Thus the importance of regions lies in their ability to act as focal points, therefore, of their capacity to unblock their own innovation resources. This aligns with the concept of regional innovation ecosystems (Isenberg 2010; Stam 2015) that focus on the creation of a production system. This perspective would lead to solutions to problems, which are partly subject to limitations related to the participation of workers in processes of change and innovation and the ways in which work is organised. Limitations that have to do, at least partly, with the lack of coalitions for learningoriented cooperation (Ennals \& Gustavsen 1999) and which affect the regional sphere (Fricke \& Totterdill 2004). Here, the regional system is considered to be "the intellectual framework to guide public action" (Coenen \& Asheim 2006).

As a result, the links between the organisation of work and the dynamics of innovation at a company level (and other sectoral, regional and national innovation systems) can influence the improvement of the innovation capacities of workers (Fricke 1983) and the transformation of ideas into new products and processes (Arundel et al. 2007) through workplace innovation.

\section{Policies, Programmes and Public intervention.}

A form of public intervention for the generation of workplace innovation is carried out by means of designing public policies. Specifically, through "a set of techniques by which governmental authorities wield their power in attempting to ensure support and effect or prevent social change", also called instruments (Vedung 1998: 2). In general, the instruments are divided into three groups; as regulations, economic transfers and soft instruments (e.g. Borrás \& Edquist 2013). Soft instruments our distinguished from the others due to their voluntary and non-coercive nature, where public and private stakeholders establish forms of cooperation that are not strongly hierarchical and where there is a mutual exchange of information (Borras \& Edquist 2013: 1516). This is why the instruments are recurrent, due to their usefulness when the diversity of stakeholders and the complexity of the intervention subjects is high (Trubek \& Trubek 2005), or to guide learning processes and experimentation in the design and implementation of public policies.

In Europe, as regards participation, public intervention has not always led to legislative reforms, but rather to soft forms of regulation (Forsyth et al. 2006; Trubek \& Trubek 2005; Alasoini 2008; Alasoini et al. 2017). Thus, a programme is ideally identified as a soft instrument of political intervention. From an institutional perspective, programmes are understood as an activity with a set duration (Alasoini 2011: 30). This means orienting research towards the institutional separation (Alasoini 2008) between jobs and the innovation policy.

Conceptually, programmes are characterised by 1) simultaneously gathering a broad range of organisations within a defined time frame, 2) the agreement on the content of the framework between the workers, the employees and other stakeholders (social agents, research, education, government). And 3) that the participants in the programme are committed to the exchange of information and cooperation (interaction) (Alasoini 2008: 63).

The programmes, as instruments to obtain workplace innovation, can be considered as production systems and development systems. In their ideal form, the programmes must be capable of renewing 
themselves (learning from the programme) and of contributing towards improving the activities of the programme within a broader context (learning of policies) (Alasoini 2016: 53). As a production system, a programme must produce results in productivity and QWL at micro and macro levels (Alasoini 2016: 83-84), while, as a development system, a programme must generates learning at the level of programmes and at the level of public policy. From this approach, Programmes as the instruments of public policies have raised interest, in particular in relation to the impacts of technological change derived from digitalisation, robotisation and the automation of work processes and the way these challenges are tackled through the modernisation of socio-economic institutions (Pérez 2004; Freeman \& Perez 1988) and the role of the Public Administration (Mazzucato 2014).

\section{The regional approach in the Basque Country.}

The participation of workers has acquired relevance in the political agendas of the Basque Country. Most of the arguments in favour of the participation of workers are currently based on aspects that link the increase in business competitiveness with higher levels of organisational innovation.

An interesting example in the search for solutions are the worker participation programmes promoted by the Government of the Basque Autonomous Community (NUTS2) and the Provincial Government of Gipuzkoa (NUTS3) implemented starting in 2013. Both are included as instruments to support innovation in the STI Plan.

The next section summarises the innovation policy of the Basque Autonomous Community and its evolution and describes the participation-based promotion programmes. According to the aims of this article, the focus is on participation in terms of workplace innovation and leaves out of its scope of analysis other programmes to foster the social economy or co-operativism.

\section{Background}

The evolution and track record of the Science, Technology and Innovation policy in the Basque Country dates back to three decades ago, in the 1980s, and is characterised by its continuity (OECD 2011: 42). The institutional configuration of the Basque Autonomous Community, its self-government capacity, the regime of competences transferred from the Spanish central Administration and the characteristic fiscal decentralisation in the provinces it is comprised of, make the region a holistic case study within the framework of regional public policies (Navarro et al. 2013).

The development of the policies and the evolution of the STI System can be structured into three phases. The decade of the 1980s is defined by the constitution of the Government of the Basque Autonomous Community after the end of Franco's regime and focuses on the industrial reconversion of the Basque economy. This phase has its greatest exponent in the creation of technology centres that reaches its highest point with the creation of the Network of STI Agents in 1997.

All this leads to a subsequent phase, focused on improving the efficiency of Basque companies, fostering non-R\&D-based diversification and internationalisation in the late 1990s. During this period, known as the combined offer and demand policy, efforts focus on the consolidation and concentration on priorities in technological knowledge and innovation among the main business and social stakeholders.

During the 2000s, the third phase, the system evolves towards an approach of innovation and sciencedriven industrial diversification, known as the results-oriented policy, whose main objectives were aimed both at the diversification of the business fabric and at achieving results in terms of science, technology and innovation (Valdaliso 2015). During this phase the Basque STI Council was created 
(2007), as the body for participation in STI policies, comprised by the Basque Government and the three provincial (sub-regional) administrative institutions.

Innovation strategies and policies in the Basque Country have prioritised an R\&D-based technological policy model, with a clear industrial orientation in comparison to other non-R\&D-based scientific or innovation models. In general terms, the innovation strategy and policy has been more focused on offer (creation of infrastructures) than on demand (absorption capacity of companies). This results in low levels of organisational innovation. Part of these deficiencies have been associated with the difficulty to create learning spaces in workplaces (Orkestra 2015: 24) and with the governance structure of companies (Navarro 2010a).

\section{The STI Plan}

With the arrival of the new plan (PCTI 20202) in 2014, which includes the Smart Specialisation Strategy promoted by the European commission. As such, the Plan focuses on three strategic priorities (Advanced Manufacturing, Energy, Biosciences/Health) that are implemented in six objectives, one of them in particular based on an increase in the number of innovative companies. The objective of the Plan is expressed as follows:

"To improve the well-being, sustainable economic growth and employment of Basque society by means of a research and innovation policy based on smart specialisation and on the improvement of the efficiency of the Science, Technology and Innovation System (STI Plan 2020)".

In the new strategy, business innovation is of a cross-cutting nature. The low levels of technological and non-technological innovation and the failure to achieve the objectives of the previous 2015 Plan contextualise the framework for the instruments to support the innovation ecosystem of the new STI plan in the 2020 horizon. As regards the levels of non-technological innovation, it should be mentioned that the levels, far from improving, fall during the period (2010-2015) of the preceding plan (STI Plan 2020).

\section{The STI Network}

From the point of view of the components of the system, the Basque Administration has carried out a policy that has been strongly mediated by the activity of technology centres. But with the adoption of the new plan, the Network of STI agents (2015) has been reorganised, and there is a restructuring of the public expenditure started in 1990. Based on this re-orientation, problems (offer and demand) are identified, such as the lack of specialisation and research capacity and the lack of absorption capacity of companies (Navarro 2010b; Valdaliso 2010). After the change, the Network3 is structured by 120 organisations that comprise the regional innovation system in three sub-systems; scientific and university (universities and research centres of excellence); technological innovation and development (technology centres, certification and laboratory entities, company R\&D units, healthcare R\&D units, etc.); and support for innovation (technology parks, intermediaries, etc.).

As for companies, the Basque administration implements an indirect support policy, by means of developing infrastructures (provision of technology), not directly oriented towards the improvement of

${ }^{2}$ http://www.euskadi.eus/contenidos/informacion/pcti_euskadi_2020/es_def/adjuntos/pcti_libro_en.pdf

${ }^{3}$ According to the assessments carried out (Morgan 2013), the Basque country is considered to be a European region with a high level of institutional thickness (Amin \& Thrift 1995). 
absorption capacities (Navarro 2010b). The analysis of the economic production fabric for the 20102015 period describes a "pattern of innovation oriented towards the development of technological innovation (characterised by high R\&D expenditure, innovation oriented towards new products and processes and a significant profile of STI collaborations), of a markedly incremental nature (development of products that only represent a novelty for the company), with the characteristic effects of an operation strategy in the company (that is, it increases the quality of the current product or increases the product range), repetitive over time and concentrated in medium and large companies (with more than 50 workers)" (Orkestra 2017: 78-79).

\section{The instruments (policy mix)}

The instruments included in the Plan (see picture 1) range from programmes for technological upskilling, to the generation of skills, the convergence of skills and cooperation in R\&D and support for innovation. The main beneficiaries of the instruments are companies (strengthening of technological and innovative skills) and the agents of the Network (reinforcement of scientific and technological skills). The instruments grouped in the above categories consist of support programmes and services for companies, as well as for agents in the $R \& D$ value chain.

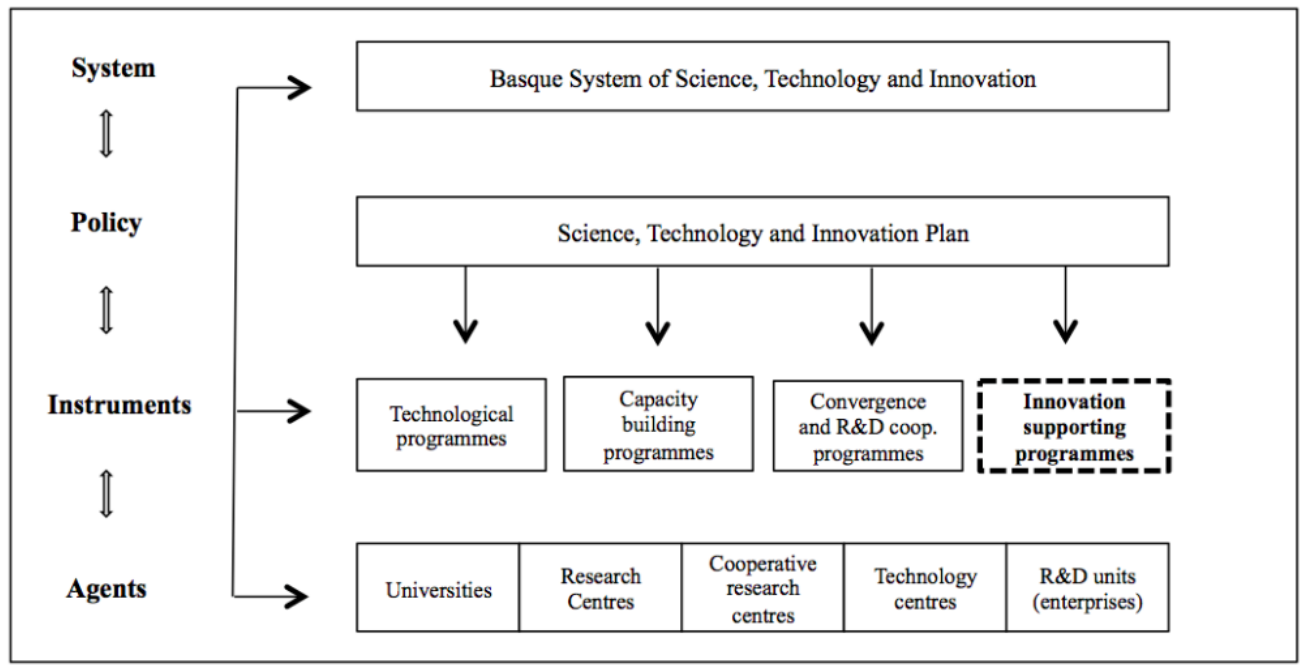

Picture 1: Policy mix instruments contained in the STI Plan

Source: Basque Government - STI Policy mix instruments.

As pointed out, interest in participation in the design and orientation of the policies is marked by the weakness of the innovative capacity of Basque companies. The analyses carried out associate the lack of adjustment between the innovation input and the impact of the innovation with the lack of adequate organisational models for the exploration and exploitation of knowledge (Orkestra 2017: 78-79).

Within this context, during the 2013-2014 period some participation programmes were launched in the Basque Autonomous Community, defined as support instruments within the policy mix of the STI Plan. The next point describes two approaches; a regional programme (RP) and a sub-regional or provincial level programme (SP) oriented towards the promotion of participation and an increase in business innovation.

\section{The programmes: two approaches to the promotion of participation.}

It should be clarified that although the two programmes are included as instruments to support the 
policy mix of the STI Plan, the origin and design come from Administrations at different administrative-territorial levels. The regulatory competences for innovation are at an Autonomous Community level; however, the STI Plan is governed by the Basque STI Council, where the government of Gipuzkoa (with a sub-regional scope) participates. On the other hand, even though the SP instrument is incorporated as an instrument to support the plan, its origin is in the territory's social economic development policy (one third of the Autonomous Community). A more detailed analysis of these and other implications, such as multilevel governance, have been developed in some analyses (Pomares 2018; Pomares et al. 2016).

In general terms, the central idea of both programmes consists of expanding the objective of the innovation policy, focusing on positive results derived from technological and non-technological innovations. In both cases, the RP and SP programmes are defined by the use of concepts such as workplace innovation, participation, social innovations, non-technological innovations, organisational process innovations and organisational innovations, in line with those used in other models of European programmes (Business Decisions Limited 2000; Brödner \& Latniak 2003; Eeckelaert et al. 2012; Oeij et al. 2017).

A reasoning that underlies both Programmes is that, although they are contextualised within a framework to foster endogenous development and an increase of the levels of business innovation, the issue of the relocation of the decision-making centres of companies is recurrent in the narratives that support participation (in particular participation in the capital or financial participation, also promoted by both programmes by means of deductions or tax incentives).

\section{The Regional Programme (RP) and the Sub-regional Programme (SP).}

The Regional Programme (RP) started its activity in 2014 and has its origins in the policies of the Department of Competitiveness (Basque Government) and the business development Agency (SPRI). The programme also includes the participation of the three provincial Administrations that comprise the Basque Country. The geographical scope of this programme is the Basque Autonomous Community and is of a sectoral nature due to its origin in the Industry Plans (2014-2016). This programme limits participation to companies with industrial activities and with 10 employees.

This annual programme is mainly aimed at companies, by financing the preparation of diagnoses, the design of plans and their follow-up in financial participation, management and results projects. The programme establishes a prior diagnosis as a condition, an activity that can be carried out internally or by hiring external experts. This approach has its origin, as has been indicated, in the high percentage of companies with certification systems in advanced management or total quality models (TQM). 
Table 2: Objectives of the Programmes

\begin{tabular}{lll}
\hline Objectives & Regional Programme (RP) & Sub-regional Programme (SP) \\
\hline Programme-level & $\begin{array}{l}\text { To support the development of } \\
\text { competitive improvement activities in } \\
\text { companies through actions aimed at the } \\
\text { participation of Company workers. }\end{array}$ & $\begin{array}{l}\text { To promote the grounding, continuity and } \\
\text { competitiveness of companies through the } \\
\text { co-responsible, active and effective } \\
\text { participation of all the people in the } \\
\text { company. }\end{array}$ \\
\hline Generative level & $\begin{array}{l}\text { Limited to individual projects; not } \\
\text { oriented towards the dissemination of } \\
\text { new practices, models, etc... }\end{array}$ & $\begin{array}{l}\text { It considers dissemination and expansion as } \\
\text { one of the main activities of the } \\
\text { Programme }\end{array}$ \\
\hline Workplace level & $\begin{array}{l}\text { To improve the capacity of sectoral } \\
\text { organisations through the preparation of } \\
\text { individual projects based on diagnoses, } \\
\text { plans and the implementation of } \\
\text { participative organisational models. }\end{array}$ & $\begin{array}{l}\text { To increase the number of organisations } \\
\text { with participative models through } \\
\text { individual projects in cooperation and/or as } \\
\text { a network through R\&D, its expansion and } \\
\text { dissemination. }\end{array}$
\end{tabular}

Source: own elaboration

The Sub-regional Programme (SP) starts its activity in 2013 and is created by the Department of Economic Promotion (Provincial Government of Gipuzkoa). Its geographical scope is provincial/subregional and is based on the territorial socio-economic development policy. Unlike the regional programme, it does not establish sectoral limits over the type of activity or the number of employees, and considers other social, economic, education and production agents as stakeholders. The programme finances $R \& D$ activities and projects, in addition to the expansion and dissemination of the resulting experiences. 
Table 3: WPI programmes as policy instruments contained in the STI Plan

\begin{tabular}{lll}
\hline $\begin{array}{l}\text { Name of the } \\
\text { instrument }\end{array}$ & Innobideak Pertsonak (RP) & Participation Programme (SP) \\
\hline Scope & Regional (NUTS2) & Sub-regional / Provincial (NUTS3) \\
\hline $\begin{array}{l}\text { Category of the } \\
\text { STI Instrument }\end{array}$ & $\begin{array}{l}\text { Support for the business innovation } \\
\text { ecosystem }\end{array}$ & $\begin{array}{l}\text { Support for the business innovation } \\
\text { ecosystem }\end{array}$ \\
\hline $\begin{array}{l}\text { Department in } \\
\text { charge }\end{array}$ & $\begin{array}{l}\text { Department of Economic } \\
\text { Development and Competitiveness - } \\
\text { Basque Government. }\end{array}$ & $\begin{array}{l}\text { Department of Economic Promotion - } \\
\text { Provincial Government of Gipuzkoa }\end{array}$ \\
\hline Origin & Industrialisation Plan 2014-2016 & $\begin{array}{l}\text { Commitment to the Territory / } \\
\text { Commitment to People strategy }\end{array}$
\end{tabular}

\begin{tabular}{lll}
\hline \multirow{2}{*}{ Description } & $\begin{array}{l}\text { To promote the participation of } \\
\text { workers in the company to improve } \\
\text { competitiveness and social cohesion. }\end{array}$ & $\begin{array}{l}\text { To promote experimentation and } \\
\text { intervention in formulas of organisational } \\
\text { innovation. }\end{array}$ \\
\hline
\end{tabular}

$\begin{array}{lll}\begin{array}{l}\text { Forms of } \\ \text { participation } \\ \text { promoted }\end{array} & \text { Participation in Management } & \text { Participation in Management } \\ & \text { Participation in Results } & \text { Participation in results } \\ & \text { Participation in Ownership } & \text { Participation in Ownership }\end{array}$

\begin{tabular}{lll}
\hline Types of Projects & Individual projects & Individual, in cooperation or in a network \\
\hline Types of activities & Initial Diagnosis & R\&D Projects \\
& Design of Plans & Diffusion project \\
& Accompaniment & \\
\hline Size of Companies & More than 10 workers & No requirements \\
\hline \multirow{2}{*}{$\begin{array}{l}\text { Participants } \\
\text { Companies (extractive industrial, } \\
\text { processing, production, technical } \\
\text { services linked to the production } \\
\text { processes of the aforementioned and } \\
\text { from the field of the information and } \\
\text { communication society). }\end{array}$} & $\begin{array}{l}\text { STI Network Agents } \\
\text { provided }\end{array}$ & $\begin{array}{l}\text { Strategic entities of an educational, } \\
\text { economic-social, local and/or regional } \\
\text { nature }\end{array}$ \\
\hline
\end{tabular}

Source: Basque Government, own elaboration 
The main difference between the two programmes is found in the type of project and the types of stakeholders that are eligible. While in the regional sphere the programme finances diagnosis processes, the preparation of plans and monitoring companies mainly from the industrial sector, in the sub-regional sphere the programme promotes $R \& D$ projects, the expansion and dissemination of business organisations, and other types of agents of the innovation system. This difference has an impact on the type of activity financed; while at the regional level only individual projects in workplaces are considered, the sub-regional programme extends financing to projects in co-operation with other organisations (social, economic, educational, strategic) and/or companies, as well as for the creation of networks.

Both programmes have their own particular designs and orientations. The RP has a limited scope due to its sectoral nature, limiting participation to individual projects that must follow a diagnosis-based logic, the preparation of plans and their implementation. The participation of education, social or research agents is not possible, and the programme does not establish mechanisms or instruments that make the dissemination of the knowledge generated possible.

With a broad orientation, in that it includes a wide variety of stakeholders (universities, vocational training centres, trade unions, business associations, STI network stakeholders) in the development of individual projects, in co-operation or as a network, the RP guides the activities towards research and the development, dissemination and expansion of the knowledge generated within the framework of the programme.

\section{Discussion}

Based on the different approaches to the innovation systems revised, the Basque innovation system can be classified as traditional. The participation of workers as an element to seek innovative solutions to the organisation of work has acquired certain relevance and visibility in the Basque Country starting in the 2010s. However, in the early 1990s, the organisational structure of Basque companies was simple due to the employment size. The evolution and changes in the organisation of work in organisations of the Basque Country has been incentivised, in particular by the ISO certification systems and European Foundation Quality Management (EFQM). This evolution took place in particular from 1992 onwards, with the creation of the Basque Foundation for Quality (Euskalit). Starting in 2010, the region is at the lead with the highest number of awarded companies in the European scoreboard. Similarly, it takes place with the proliferation of Corporate Social Responsibility strategies adopted by companies, particularly due to their perception and assessment as an instrument for the improvement of social commitment and relations with employees, which has its impact (Unceta \& Gurrutxaga 2005).

The incorporation of new technologies, the higher intensity in $R \& D$ and changes in the markets are identified as the main causes among company directives (1996-2001) behind the changes in organisation and management structures, management tools and techniques and the human resource base of companies. In the early 2000s, there is an increase in practices such as ISO 9000 quality management systems, occupational risk prevention plans, diagnosis and training plans, competitor analyses, customer satisfaction surveys, mission and vision definitions, treasury management systems, 5s and continuous improvement (Lahera 2004; Valdaliso 2010; Guler et al. 2002). The type of practices offers an idea of the type of rhetoric and the management style of directives (Barley \& Kunda 1992; Abrahamson 1996) used during the period described.

The field studies carried out at machine-tool companies show that the adoption of new forms of work organisation are carried out, mainly, based on regulations and work procedure descriptions designed in technical offices, demonstrating the absence of use of participative forms (carried out directly or by means of representatives) (Lahera 2004). 
Although the Basque Country has a tradition, shown through the co-operative experience of Mondragon (MCC) and its broad social capital as a foundation for high levels of co-operation (business to business and business to technology centres), the participation of workers from the perspective of workplace innovation or organisational innovation has barely been studied. Most of the improvements in working conditions have been related to the production capacity model and to collective bargaining.

The Basque Country has been a region rich in negotiation, particularly in the industrial sector. However, recent labour reforms, in particular that of 2012, change this situation; workers covered by an agreement negotiated In the Basque Autonomous Community, after lodging complaints and the non-renewal of the agreement, go on to depend on a state-level agreement or find themselves without the coverage of any agreement at all. According to the Basque Council of Labour Relations4 (2017) during the 2011-2017 period, state-level agreements have grown in terms of coverage (affected workers) by $20 \%$, while during the same period the agreements recorded in the Basque Autonomous Community fell by 35\%. In addition, most of the agreements relinquished from 2013 onwards are particular agreements recorded in the Basque Country (Consejo Vasco de Relaciones Laborales 2017).

As for non-technological innovations (organisational and marketing), the indicators5 of the Regional Innovation Scoreboard 2017 show that the percentage of innovative Basque companies in these fields is still low in the regional European scoreboard. Navarro (2010a) points to evidence about forms of work organisation based on constrained learning models (Lorenz \& Valeyre 2005), as opposed to the forms based on discretionary learning, more typical of the more innovative regions at levels higher than the regional sphere (NUTS 1). Huerta \& García (2004), quoted in Navarro 2010a, point to the culture of quality and the inertia of old organisation models as an obstacle for the emergence of new ways of organising work.

\section{Conclusions}

As we have seen, one of the weaknesses of the Basque system is in the low levels of organisational innovation. One way to improve the absorption capacity of regional companies could be through programmes to change the governance and control structures of organisations (Navarro 2010a). Establishing the focus of innovation on companies and workers by means of programmes can lead to effects on the creation of institutions to search for solutions capable of generating improvements in the productivity and quality of work, and the creation of bridges among the different knowledge bases available in the region.

Faced with these matters, it seems necessary for the Administration to not only foster and promote them, but also to learn how to develop horizontal and participative public policies with the stakeholders of the innovation system. The programmes represent institutional frameworks which can contribute towards transforming organisational models through public entrepreneurship, insofar as are capable of attracting a critical number of stakeholders and organisations in a research, co-operation, information exchange and regional interaction process (Fricke \& Totterdill 2004). It is therefore important to consider the gaps of political knowledge, and to explore in more depth issues such as the design, process and dissemination of workplace innovation;

- Design knowledge refers to the ability to explore the current and future scenarios of

\footnotetext{
4 The Basque Council of Labour Relations is a public institution created as a body for permanent dialogue and meetings between the trade union and business confederations and as a consultant body for social and occupational matters for the Basque Government and Parliament. It is participated by the most representative trade unions and business associations.

5 https://ec.europa.eu/docsroom/documents/24186
} 
companies;

- Process knowledge means helping companies to find adequate ways to implement participative processes of change on the foundation of theories or models of change and development intervention;

- Dissemination knowledge is useful to support the transfer and dissemination of experiences and processes of change and intervention for the benefit of the stakeholders that do not participate in the projects (Alasoini 2011: 30-38).

Understanding the programmes as an institutionalised activity (Alasoini 2011) means building spaces for learning and cooperation that can bring together a critical mass of organisations and stakeholders (Ennals \& Gustavsen 1999) as a source for the production of innovations in learning based on the design of instruments and public policies with a social impact (Lundvall 1999).

\section{References}

Abrahamson E. (1996). "Management fashion". Academy of Management Review, 21(1), 254-285. Alasoini T. (2004). "The new Finnish workplace development programme (TYKES-FWDP) as an approach to innovation". Concepts and Transformation, 9(3), 279-295.

Alasoini T. (2005)." Learning networks as creators and disseminators of generative ideas". The Finnish Workplace Development Programme as an expanding activity, 136.

Alasoini T. (2006). "In search of generative results: a new generation of programmes to develop work organization." Economic and industrial democracy, 27(1), 9-37.

Alasoini T. (2008). "Building better programmes: learning networks in the promotion of workplace innovation". International Journal of Action Research, 4(1+2), 62-89.

Alasoini T. (2011). "Workplace development as part of broad-based innovation policy: Exploiting and exploring three types of knowledge." Nordic journal of working life studies, 1(1), 23-43.

Alasoini T. (2012). “A New Model for Workplace Development in Finland. Rethinking Employee Participation and the Quality of Working Life in the Context of Broad-based Innovation Policy". International Journal of Action Research, 8(3).

Alasoini T. (2013). "Rethinking employee contribution: A framework for promoting employee-driven innovation". In Proceedings of the 8th European Conference on Innovation and Entrepreneurship ECIE (pp. 9-16).

Alasoini T. (2016). Workplace Development Programmes as Institutional Entrepreneurs-Why They Produce Change and Why They Do Not. (Doctoral Dissertations, Aalto University, 12/2016)

Alasoini T., Ramstad E. \& Rouhiainen N. (Eds.) (2005), The Finnish Workplace Development Programme as an Expanding Activity. Results, Challenges, Opportunities, Tykes Reports 47, Ministry of Labour, Helsinki.

Alasoini, T., Ramstad, E. \& Totterdill, P. (2017). "National and regional policies to promote and sustain workplace innovation." In Workplace Innovation (pp. 27-44). Springer, Cham.

Amin A., \& Thrift N. (1995). Globalization, institutions, and regional development in Europe. Oxford University Press.

Arnkil R. (2004). “The Finnish workplace development programme: A small giant?". Concepts and Transformation, 9(3), 249-278.

Arnkil R., Järvensivu A., Koski P. \& Piirainen T. (2010). "Exploring the quadruple helix". Report of quadruple helix research for the CLIQ project.

Arundel A., Lorenz E., Lundvall B. A. \& Valeyre A. (2007). "How Europe's economies learn: a comparison of work organization and innovation mode for the EU-15"'. Industrial and corporate change, 16(6), 1175-1210.

Asheim B. (2007). Differentiated knowledge bases and varieties of regional innovation systems". Innovation, 20(3), 223-241. 
Asheim B. T., \& Gertler M. S. (2005). "The geography of innovation: regional innovation systems". In The Oxford Handbook of Innovation. Oxford University Press, Oxford.

Asheim B. T., Smith, H. L. \& Oughton C. (2011). "Regional innovation systems: theory, empirics and policy." Regional studies, 45(7), 875-891.

Asheim B., Isaksen A., Nauwelaers C. \& Tödtling F. (Eds.) (2003). Regional Innovation Policy For Small-Medium Enterprises. Edward Elgar, Cheltenham.

Asheim B.T., Bugge M. M., Coenen L. \& Herstad S. (2013). "What does evolutionary economic geography bring to the policy table? Reconceptualising regional innovation systems." Papers in Innovation Studies, 5.

Barley S. R., \& Kunda G. (1992). "Design and devotion: Surges of rational and normative ideologies of control in managerial discourse." Administrative Science Quarterly, 363-399.

Bauer T. K. (2004). "High performance workplace practices and job satisfaction: Evidence from Europe". Institute for the Study of Labor Discussion Paper 1265.

Borrás S., \& Edquist C. (2013). "The choice of innovation policy instruments." Technological forecasting and social change, 80(8), 1513-1522.

Borrás S., Chaminade C. \& Edquist C. (2009). "The challenges of globalization: strategic choices for innovation policy. The Innovation Imperative: National Innovation Strategies in the Global Economy, 7-23.

Boxall P., \& Purcell J. (2011). Strategy and human resource management. Macmillan International Higher Education.

Brödner P. \& Latniak E. (2003). Sources of innovation and competitiveness: National programmes supporting the development of work organisation." Concepts and transformation, 8(2), 179211.

Business Decisions Limited (2000) Government Support Programmes for New Forms of Work Organisation: A Report for DG Employment \& Social Affairs. Luxembourg: Office for Official Publications of the European Communities.

Chaminade C. \& Edquist C. (2006). "From theory to practice: the use of the systems of innovation approach in innovation policy". Innovation, science, and institutional change, 141-160.

Coenen L. \& Asheim, B. (2006): "Constructing Advantage at the Northern Edge", in Cooke P. \& Piccolug A. (eds.), Regional Development in the Knowledge Economy, Routledge, 84-111.

Consejo Vasco de Relaciones Laborales (2018). Situación económica y relaciones laborales en la CAPV 2017. Accedido el 20 de marzo, 2019 en: http://www.crllhk.eus/images/infSociolaboral/Anual/Informe_sociolaboral_CRL_2017.pdf

Cooke P., Boekholt P. \& Tödtling F. (2000). The Governance of Innovation in Europe. Pinter, London.

Cressey P., Totterdill P. \& Exton R. (2013). "Workplace social dialogue as a form of' productive reflection". International Journal of Action Research, 9(2), 209.

Doloreux D. \& Parto S. (2005). Regional innovation systems: Current discourse and unresolved issues. Technology in society, 27(2), 133-153.

Edquist C. (1997). Systems of innovation: Technologies, organisations and institutions. Pinter, London.

Edquist C. (2001). "The Systems of Innovation Approach and Innovation Policy: An account of the state of the art". In DRUID conference, Aalborg (pp. 12-15).

Edquist C., Luukkonen T. \& Sotarauta M. (2009). "Broad-based innovation policy", in Evaluation of the Finnish National Innovation System - Full report. (Taloustieto Oy, Helsinki University Print: Helsinki) 11-54

Eeckelaert L., Dhondt S., Oeij P., Pot F. D., Nicolescu G. I., Webster J. \& Elsle, D. (2012). Review of workplace innovation and its relation with occupational safety and health. Bilbao: European Agency for Safety and Health at Work.

Ennals R., \& Gustavsen B. (1999). Work organization and Europe as a development coalition (Vol. 7). John Benjamins Publishing. 
European Commission. (2012). Guide to research and innovation strategies for smart specialisations (RIS3). Brussels: European Union. May 2012.

Forsyth A., Gahan P. G., Howe J. \& Mitchell R. (2006). Regulating for innovation in workplace production and employment systems: A preliminary discussion of issues and themes.

Freeman C. (1987). Technology policy and economic policy: Lessons from Japan. London: Pinter.

Freeman C. \& Perez C. (1988). Structural crises of adjustment: business cycles. Technical change and economic theory. London: Pinter.

Fricke W. (1983). "Participatory research and the enhancement of workers' innovative qualifications." Journal of occupational behaviour, 73-87.

Fricke W. \& Totterdill P. (Eds.). (2004). Action research in workplace innovation and regional development (Vol. 15). John Benjamins Publishing.

Gobierno Vasco (2014). Plan de Industrialización 2014-2016. Gobierno Vasco.-(2013): Plan de Internacionalización Empresarial, 2016.

Gobierno Vasco (2015). PCTI Euskadi 2020: Una Estrategia de Especialización Inteligente.

Guler I., Guillén M. F. \& Macpherson J. M. (2002). "Global competition, institutions, and the diffusion of organizational practices: The international spread of ISO 9000 quality certificates." Administrative science quarterly, 47(2), 207-232.

Huerta E. \& García C. (2004). La innovación tecnológica y organizativa en la empresa industrial vasca. SPRI y Universidad Pública de Navarra.

Isenberg D. J. (2010) "How to start an entrepreneurial revolution", Harvard Business Review, 88(6), pp. 41-50.

Jensen M.B., Johnson B., Lorenz E. \& Lundvall B.A. (2007) "Forms of knowledge and modes of innovation." Research Policy 36, 680-693.

Kline S. J. \& Rosenberg N. (2010). "An overview of innovation.” In Studies On Science And The Innovation Process: Selected Works of Nathan Rosenberg (173-203).

Lahera A. (2005). Enriquecer el factor humano. Paradigmas organizativos y trabajo en grupo, El Viejo Topo, Madrid.

Lahera A. (2004). La participación de los trabajadores en la democracia industrial (Vol.

Lorenz E. \& Lundvall B. ̊.. (Eds.). (2006). How Europe's economies learn: coordinating competing models. Oxford University Press.

Lorenz E. \& Valeyre A. (2005). "Organisational innovation, human resource management and labour market structure: A comparison of the EU-15." Journal of industrial relations, 47(4), 424-442.

Lundvall B. Å., (1999). "Technology policy in the learning economy." Innovation policy in a global economy, 19-34.

Lundvall B. A.., (Ed.). (1992). National systems of innovation: Toward a theory of innovation and interactive learning. London: Printer.

Lundvall B. Å. \& Borrás S. (1997). "The globalising learning economy: Implications for innovation policy”. Nelson R. R. (Ed.). (1993). National innovation systems: a comparative analysis. Oxford University Press.

Lundvall B. A.., 2004. "Why the new economy is a learning economy". DRUID Working Paper No 0401, Department of Business Studies, Aalborg University, Aalborg.

Lundvall B. A., 2008. National innovation systems - analytical concept and development tool.” Industry and Innovation, 14(1): 95-119.

Mazzucato M. (2014). Estado emprendedor: mitos del sector público frente al sector privado. Barcelona: RBA.

Metcalfe J. S. \& Hughes K. (1993). "Technology policy and innovation systems from an evolutionary perspective". In The future of UK competitiveness and the role of industrial policy (p. 226). Policy Studies Institute.

Morgan K. (2013). Basque Country RIS3: an expert assessment on behalf of DG regional and urban policy. 
Navarro M. (2010a). "Reflexiones sobre el sistema y las políticas de innovación del País Vasco". Working Papers 2010R04, Orkestra - Basque Institute of Competitiveness.

Navarro M. (2010b). Retos para el País Vasco, tras tres décadas de desarrollo del sistema y de las políticas de innovación. EKONOMIAZ. Revista vasca de Economía, 25(03), 136-183.

Navarro M. (2015). Las estrategias territoriales para la transformación productiva. Reflexión desde el caso del País Vasco. Revista Icade. Revista de las Facultades de Derecho y Ciencias Económicas y Empresariales, (96), 75-104.

Navarro M., Valdaliso J. M., Aranguren M. J. \& Magro E. (2013). "A holistic approach to regional strategies: The case of the Basque Country." Science and Public Policy, 41(4), 532-547.

OECD (2005). Innovation, Policy and Performance: A cross-country comparison. OECD, Paris.

OECD (2011). OECD Reviews of Regional Innovation-Regions and Innovation Policy. OECD, Paris.

Oeij P., Rus D. \& Pot F. D. (Eds.). (2017). Workplace innovation: Theory, research and practice. Springer.

Orkestra - IVC (2015). Informe de Competitividad del País Vasco 2015. Publicaciones de la Universidad de Deusto, Bilbao.

Orkestra - IVC (2017). Informe de Competitividad del País Vasco 2017. ¿Y mañana?. Publicaciones de la Universidad de Deusto, Bilbao.

Pérez C. (2004). Revoluciones tecnológicas y capital financiero: la dinámica de las grandes burbujas financieras y las épocas de bonanza. Siglo XXI.

Piirainen, T. \& Koski P.: "Finnish Workplace Development Programme (TYKE-FWDP) from innovation policy perspective.” In Arnkil R., Rissanen P., Pitkänen S., Piirainen T., Koski P., Berg P., Vartiainen M., Gustavsen B., Ekman Philips M., Finne H. \& Riegler C.: The Finnish Workplace Development Programme: a small giant? Finnish Workplace Development Programme - Ministry of Labour. Helsinki 2003, 26-68..

Piirainen T. \& Koski P.: "Integrating workplace development policy and innovation policy: a challenging task. Experiences from and reflections on the Finnish Workplace Development Programme." In Fricke W. \& Totterdill P. (eds.): Action research in workplace innovation and regional development. John Benjamins. Amsterdam - Philadelphia 2004, 313-331.

Pomares E. (2018). "Alternative Learning Frameworks: Workplace Innovation Programmes and Smart Specialisation Policies in the Basque Country. International Journal of Action Research, 14(2/3), 181-201

Pomares E., Luna Á. \& Unceta A. (2016). Patterns of workplace innovation in the Basque Co Eurountry: Challenges and lessons from Gipuzkoa." European Journal of Workplace Innovation, 2(2), 106-127.

Pot F. (2011). "Workplace innovation for better jobs and performance." International Journal of Productivity and Performance Management, 60(4), 404-415.

Pot F. D., Totterdill P. \& Dhondt S. (2016). Workplace innovation: European policy and theoretical foundation. World Review of Entrepreneurship, Management and Sustainable Development, 12(1), 13-32.

Schienstock G. \& Hämäläinen T. (2001). Transformation of the Finnish innovation system: A network approach. Helsinki: Sitra.

Stam E. (2015). "Entrepreneurial ecosystems and regional policy: a sympathetic critique." European Planning Studies, 23(9), 1759-1769.

Tödtling F. \& Trippl M. (2005). "One size fits all?: Towards a differentiated regional innovation policy approach." Research policy, 34(8), 1203-1219.

Tödtling F., Asheim B. \& Boschma, R. (2013). "Knowledge sourcing, innovation and constructing advantage in regions of Europe". European Urban and Regional studies, Vol. 20 No. 2, pp. 161169.

Totterdill P. (1999). "Workplace innovation as regional development." Concepts and Transformation, $4(1), 23-43$. 
Trubek D. M. \& Trubek L. G. (2005). "Hard and soft law in the construction of social Europe: the role of the open method of co-ordination." European Law Journal, 11(3), 343-364.

Unceta A. \& Gurrutxaga G. (2005). Responsabilidad Social Corporativa en el País Vasco. Paradox, Bilbao.

Valdaliso J.M. (2010). Treinta años de cambios en las empresas vascas: un estudio exploratorio y descriptivo. EKONOMIAZ. Revista vasca de Economía, 25(03), 194-221.

Valdaliso J.M. (2015). "Capítulo 1. Marco teórico", en Orkestra, Cuadernos del Informe de Competitividad del País Vasco 2015. Número 3: Sectores y Clústeres. Bilbao: Publicaciones Deusto.

Vedung E. (1998). "Policy instruments: typologies and theories". In Carrots, Sticks and Sermons: Policy Instruments and Their Evaluation M. L. Bemelmans-Videc, R. C. Rist and E. Vedung (eds). New Brunswick, NJ: Transaction Publishers, 21-58.

Woolthuis R. K., Lankhuizen M. \& Gilsing V. (2005).” A system failure framework for innovation policy design." Technovation, 25(6), 609-619.

\begin{abstract}
About the author
Egoitz Pomares is researcher at Sinnergiak, University of the Basque Country (Spain). He researches on workplace innovation and regional public policy programmes on workplace development at Sinnergiak Social Innovation, a research organisation of the University of the Basque Country (Spain). He participates in and contributes to the European Workplace Innovation Network (EUWIN).
\end{abstract}

epomares@sinnergiak.org 